Business management replication from established market to emerging market: An analysis of the Indian Premier League from the Bangladesh market perspective

Shams, S M Riad

Central Queensland University, Australia (shamsriad@gmail.com)

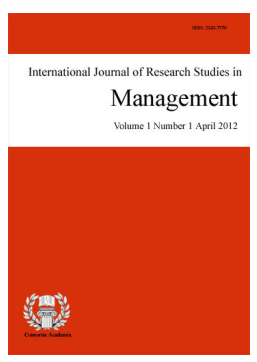

ISSN: 2243-7770 Online ISSN: 2243-7789

Received: 11 September 2011

Revised: 23 September 2011 DOI: $10.5861 /$ ijrsm.2012.v1i1.34

\title{
Abstract
}

This paper attempts to analyze the critical factors that would be crucial to replicating business management strategies from established market to emerging market. A case study is conducted on the Indian Premier League market and Bangladesh market, while these markets are considered as established and emerging markets of the Twenty 20 cricket business consecutively. Seven critical factors are identified from the study as crucial in case of replicating business management strategies from established market to emerging market. However, the implementation of the critical factors should follow only the given situation, underlying the environment of the emerging market. The findings of the study shall shed light to managerial perception from the perspective of emerging market business strategies, while the strategies are learnt from another market.

Keywords: emerging market; established market; Bangladesh Cricket Board; Indian Premier League; management strategy 


\section{Business management replication from established market to emerging market: An analysis of the Indian Premier League from the Bangladesh market perspective}

\section{Introduction}

Indian Premier League (IPL) provides a paradigm shift approach of cricket marketing in global cricket industry (Shams, 2011a). IPL not only has established the benchmark in cricket marketing, but also ensures high cricketers' salary, prolific engagement of all associated stakeholders and a solid financial platform. IPL is based on the Twenty20 format of international cricket and adapted the marketing practices of English Premier League (EBL) and American National Basketball Association (NBA). The combination of the Twenty20 cricket with the marketing strategies of EBL and NBA emerges as prolific in terms of popularity, market acceptance and revenue generation through cricket business, while popularity of the traditional format (test cricket and one day international) of the game is decreasing (Shams, 2011b). Moreover, the Twenty20 cricket brings the opportunity for the cricket world to promote the game in global level (Miller, 2009; Meher, 2009). As a result, the IPL management is also promoting the concept to other cricketing nations and International Cricket Council (ICC) in order to reach in the next level by introducing a global champion's league comprising of the champion teams of the each nation's domestic league (Vaishnav, 2009).

From this context, a case study has been conducted on IPL, with the aim of realizing how the IPL business concept would be meaningful in another market. Bangladesh market has been considered as emerging market for the Twenty20 cricket business, while the IPL market signifies its relevancy as an established market of the business. The popularity of the game in Bangladesh provides a favorable platform for the study in order to analyze the IPL business model from Bangladesh market perspective. Seven critical factors are identified from the study as significant for replicating business management strategies from established market to emerging market. However, the identified critical factors play a significant role in emerging market business strategies, especially while the strategies are learnt from another market; the implementation of the factors should follow only the given situation, underlying the market environment of the emerging market.

\section{Aim and methodology}

This research adopts a case study research methodology as an interpretive study. The fundamental aim of the study is to realize the potential of IPL business model in other cricketing nation, such as in Bangladesh. A further concern of the study is to be familiar with the market environment of the Bangladesh cricket in order to compare the viability of the IPL business model from Bangladesh market perspective.

The research utilizes the documents and/or contents review as data collection method for the content analysis of previous studies and media reports associated with IPL and Bangladesh cricket. Considering the area of the inquiry, the case has been presented in a descriptive narrative style. A pattern is identified for presenting the case and relevant issues, concepts and variables (IPL business practices) identified from the case have been analyzed through insight, intuition and impression for comprehending whether the identified issues, concepts and variables are pertinent to the area of inquiry (potential of IPL business model from the Bangladesh market perspective) by direct interpretation and or naturalistic generalization. Such a case analysis and synthesis approach has been adapted from the findings of Hamilton (1980), Hartley (1994, 2004), Dey (1995), Stake (1995, 2000, 2003), Creswell (1998), Gomm, Hammersley, and Foster (2001), Stavros (2005), and Yin (2003, 2009).

\section{Background of the Indian Premier League (IPL)}

The IPL has established a benchmark of cricket marketing in the global cricket industry just within first two seasons of its operation (Shams, 2011a). This section highlights the analysis of Shams (2011a, 2011b) in order to 
demonstrate IPL's benchmark position in the global cricket industry. The IPL is a franchisee-based professional cricket league of India based on Twenty 20 cricket, the shortest version of international cricket (Indian Premier League Cricket, 2009). Because of the huge financial platform that the IPL has built during its initial days and its further potential, the IPL has been mentioned throughout the cricket industry as the billion dollar baby (Rawnak, 2008), miracle in cricket history (Merinews, 2008), IPL money making: all gainers and no losers (Tarafdar, 2009) and so forth. According to European business and financial columnist Jonathan Squirrell (2009), the Twenty20 format of the game and its proper marketing in IPL assured the financial security of the game. Moreover, IPL has placed the Board of Control for Cricket in India (BCCI) in the top one hundred and seventy corporate entities in the world in terms of revenues (Home of IPL Cricket, 2009).

The average audience attendance in the first ever Twenty20 tournament was highest in England for a county cricket match since 1953 (The Twenty20, 2003). Lalit Modi, the former vice-president of BCCI, used the Twenty 20 format of the game along with the marketing concept of EBL and the NBA of America in 2007 to launch a professional cricket league in India. Later, within the first two seasons of the league in 2008 and 2009, the IPL has established itself as world's most revenue generating domestic cricket tournament, which is run by BCCI and approved by International Cricket Council (IPL History, n.d.; Maurya, 2009).

'The inaugural IPL is one of the richest domestic cricket tournaments in the world' (Maurya, 2009, p. 7). Also, it has been already praised by the world's top most professional cricketers as their ultimate destination to showcase their performance because of the incredible money that the IPL offers to the cricketers.

In an annual poll of the sixteen current players, conducted by the Professional Cricketers' Association, UK, eight said they are happy to cut short their national careers and play in the multi-million-dollar Twenty20 league in India (Maurya, 2009, p. 8).

According to Australian national cricketer Brett Lee (2008, n.p.n.p.), 'the cash-rich Twenty20 venture has created history in the game'. Again, Sharma, the sports columnist of Melbourne (2008, n.p.) described, the 'IPL may make Aussie cricketers' richest sports stars in Australia'. 'According to retired Australian cricketer Adam Gilchrist, IPL outshone even the Sydney Olympic Games' (Maurya, 2009, p. 8). Andrew Flintoff has confirmed that he has rejected the offer of a contract with the England and Wales Cricket Board (ECB) to play in IPL (Miller, 2009).

An ECB spokesman said that Flintoff's decision would require careful consideration, and that the board would digest the news. When fit, Flintoff remains an integral part of England's team, and he himself has stated he wants to play until the 2015 World Cup (Miller, 2009, n.p.).

IPL has renewed its 2008's US $\$ 1.026$ billion dollar ten year broadcasting contract with World Sports Group (WSG) and Sony in 2009 on US $\$ 1.64$ billion dollar for the rest of the nine years (Patil, 2009), which shows IPL's significant financial growth in just one year, although the league has established the benchmark of revenue generation, cricketers' salary and financial foundation too in the world cricket. In the first season of 2008, IPL earned Indian Rs 3,500,000,000 (IPL Season Two, 2009). Neither the IPL nor the commercial partner WSG and Sony are disclosing the exact figure of the profit from season two in 2009 (IPL Season Two, 2009), but the IPL business partners' comment indicates that IPL should have earned more profit from its second season in 2009 than the first season as the WSG and Sony described their second season's profit as, 'we have increased our profit significantly over the last year, but can't disclose' (IPL Season Two, 2009, n.p.). Consequently, IPL's profit in general should be increased more in second season than the first season as IPL has gained a higher contract with the WSG and Sony for broadcasting right and moreover the selling of broadcasting right is just one of the eight major earning sources of IPL (Shams, 2011b).

On the viewership front, IPL even outplayed the English Premier League (EPL) (Muralidharan, 2009). Furthermore, the second season of the IPL in 2009 has been more successful in South Africa instead of India (BBC, 2009) as all of the franchisees earned profit from the second season, whereas only two franchisees were 
able to earn profit from its inaugural 2008 season (Patil, 2009; UNP, 2009). From this perspective, IPL has grown from a domestic league to an international presence just within one year.

On the other hand, due to the nature of the IPL's initial contract with its various stakeholders, IPL's recession proof minimum annual profit can be calculated for up to the first ten years (Marketing Teacher, 2009; Incredible Marketing Success, 2009; A Dummies Guide to IPL, 2009; Mahadik, Prasad, Tawde, \& Lyer, 2009).

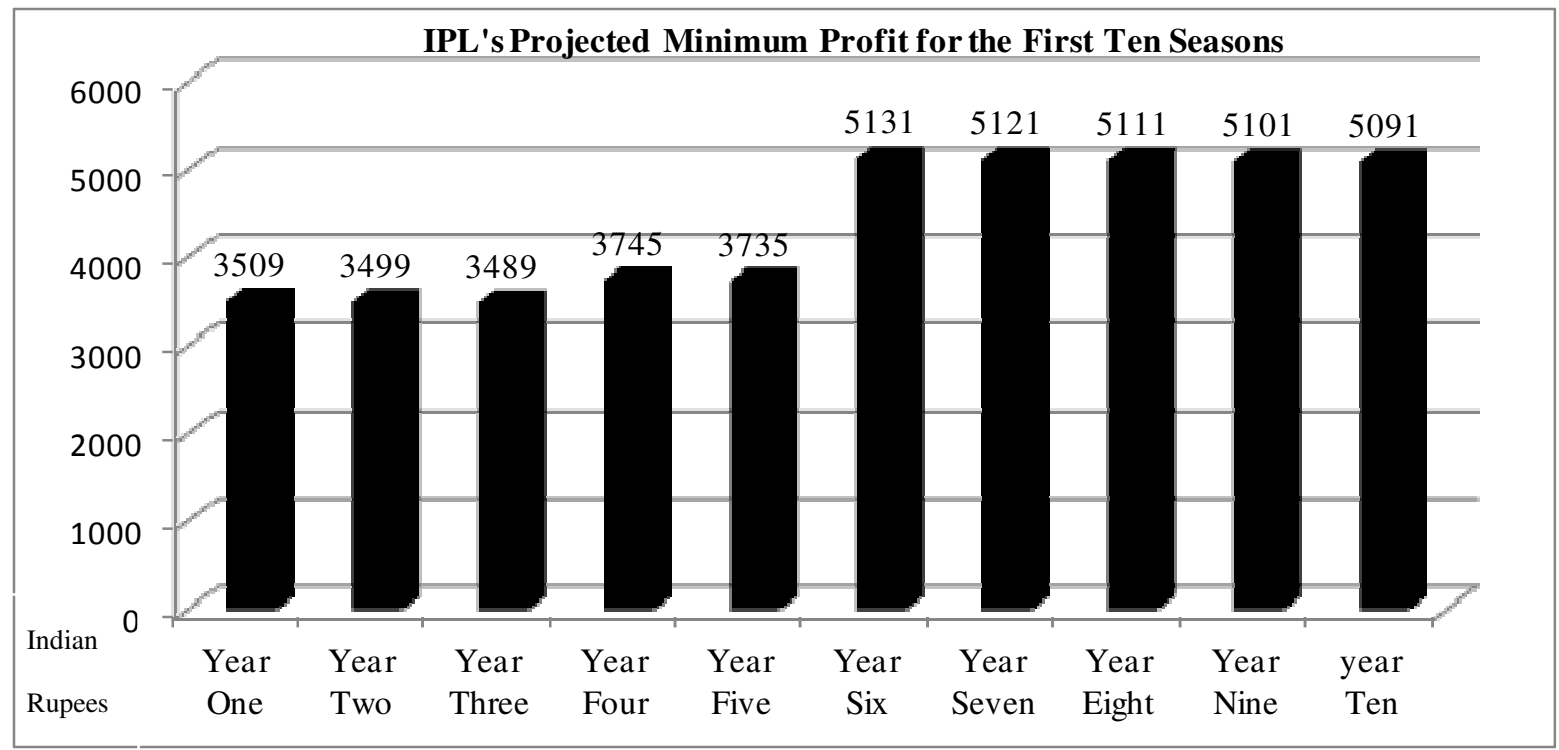

Figure 1. The Minimum Projected profit of IPL for first ten seasons (Source: Mahadik et al., 2009)

Consequently, the IPL concept has proved its global acceptance, opportunities and revenue acceleration pattern as a paradigm shift in global cricket marketing. All of the franchisees have already started to make profit just from the second season of IPL in 2009 (Patil, 2009). Rajasthan Royals already have decided to float some equity in the market and get listed on the stock exchange. On the other hand, the IPL itself as a 'golden egg spreader' has been starting to make huge profits since their inaugural season. In 2007, just after making the contracts with the stakeholders and even before 2008 as IPL's first season, BCCI's profit from only IPL was (Mahadik et al., 2009) US $\$ 87.5$ million where the rest of the ventures of BCCI earned US $\$ 58.75$ million profit for the year.

\section{Brief background of the Bangladesh Cricket}

When tigers roar, the whole world hears. Tiger is the adorable name of the Bangladesh cricket team (The Daily Star, 2007). Tiger Fan Club shows their fascinating presence in cricket venues throughout the world especially when Bangladesh plays. When Bangladesh national flag flies all over the world due to cricket, no doubt it promotes Bangladesh. Moreover, the success in cricket brought lot of international supporters of Bangladesh from all over the world. During the world cup-2007 West Indians turned into Bangladesh's supporter.

The Bangladesh team became the celebrity group everyone wants a piece of. Even the normally easy-going Taj Restaurant, where the Tigers usually had their dinner, had to be closed off for public because of the excitement and rush the Bangladesh team evoked on reaching there. People stood up and applauded on the streets, some managed Bangladeshi flags from God know where. People scurried for autographs of as the team waited to board a flight. A handshaking distance away the South African players were seated. Hardly anyone approached them (The Daily Star, 2007, n.p.). 
Business management replication from established market to emerging markets

Bangladesh has a long background of cricket (Bangla Cricket, 2006; History of Bangladesh Cricket, 2010). Bangladesh Cricket Board (BCB) is the custodian of cricket in Bangladesh. Cricket's enormous popularity with the Bangladeshi people has produced a mood of optimism (Bangladesh National Cricket Team, 2010). Reuters reported about the popularity of cricket in Bangladesh as: The Bangladesh cricket team's entry into the second round of the World Cup-2007 sparked wild celebrations around the country. The celebrations even outstrip and look like other national festival. Bangladeshis are passionate about cricket and whenever Bangladesh wins they celebrate the success (Southasiabiz, 2007). The young generation has great motivation on cricket. 'Once upon a time, football (soccer) was the premier game in Bangladesh before it was supplanted by cricket in the last ten or fifteen years among this generation' (The Daily Star, 2006, n.p.).

On the other hand, the former Captain Habibul Bashar and the former coach Dave Whatemore of Bangladesh have described that they hope Bangladesh will become a serious cricketing contender in a few years (Shams, 2011b). Bangladesh's Under nineteen team, the stepping stone before the International Test scene, regularly performs well against established Test nation's under nineteen teams. In the Under Nineteen Cricket World Cup, now days, Bangladesh participates as one of the favorites to win the title (Bangladesh National Cricket, Team, 2010). Therefore, the popularity, motivation and potential of cricket in Bangladesh extend an opportunity to introduce an IPL format of Twenty20 domestic cricket league in Bangladesh, with the aim of flourishing the latent potential of Bangladesh cricket by facilitating prolific management of cricket business, creative utilization of resources and subsequent engagement of all associated stakeholders of BCB.

\section{Analysis, findings and discussion}

Seven key issues are identified from the analysis of this study as critical factors of business management replication from established market to emerging market. The factors are:

Market potential;

$>$ Product development potential;

$>$ Relevant common feature of the established and the emerging markets;

$>$ Relevant prior exposure of the emerging market;

$>$ Implication of market relationship;

$>$ Cultural issues of the established and the emerging markets;

$>$ Endorsement and interest of the established market

The collected data has been synthesized here by direct interpretation and or naturalistic generalization approach of qualitative data analysis, suggested by Stake (2000, 2003). The seven critical factors are analyzed in the sub-section 5.1 to 5.7 of this paper by synthesizing the data, collected from the IPL and its market, and the Bangladesh market, while considering the IPL's market as established market of the Twenty20 format of cricket business, and Bangladesh market as an emerging market of the business.

\subsection{Market potential}

The popularity, enthusiasm and potential of cricket as a sport in Bangladesh is already cross-referenced in the section 4, which provides the primary anticipation and optimism of Twenty20 cricket as a business, in order to market it similar to IPL in Bangladesh.

\subsection{Product development potential}

The people of Bangladesh have much less entertainment and leisure activity alternatives. In recent years, 
some builders, event and entertainment companies, have started to utilize the gap in the market by delivering some alternate sort of entertainment and leisure activities. SM Kamaluddin (2009), chairman of the Concord group, the builder and developer company, explained his company's opportunity to gain from the Bangladesh market as 'the company is looking to address the problem of lack of entertainment facilities in the country' (n.p.), when they are trying to develop some alternate entertainment and leisure activity venue in Bangladesh to clutch the cream from the market. On the other hand, the IPL concept of cricket marketing provides enormous entertainment to the cricket loving people as the IPL has earned the comment as 'IPL is India's favorite entertainment source' (Cricket360, 2009, n.p.). Therefore, BCB has the opportunity to gain the advantage from the under-developed entertainment and leisure industry of Bangladesh by launching a domestic cricket league like IPL, which can be an alternative source of entertainment and leisure activity for Bangladeshis. Since, Bangladeshis are passionate about cricket (Shams, 2011b), BCB could utilize the opportunity from the untapped entertainment market of Bangladesh by developing and offering a Twenty 20 cricket league, with the blend of musical band performance, celebrity endorsement and/or other performing arts like IPL (Shams, 2011b), with an aim of meeting and exceeding the gap of the entertainment market.

\subsection{Relevant common feature of the established and the emerging markets}

Four relevant common features of the IPL's market and the Bangladesh market are identified, which are (Shams, 2011b):

\subsubsection{Duration and timing of a Twenty 20 match}

The duration and timing of IPL's match provide another convenient reason to get success by marketing cricket, similar to the IPL business model. Because of the Twenty20 format, each of the matches of the IPL lasts three and half hours, which is very convenient for the crowds to attend and enjoy the thrill of cricket compared to the traditional longer versions of cricket. Moreover, like IPL (Shams, 2011b), BCB can consider the prime time for the crowds as weekday evenings and weekend afternoons to schedule the matches to play so that crowds could enjoy the match during their convenient time.

\subsubsection{Commercial opportunity}

The proposed league for Bangladesh like IPL provides enormous opportunity of revenue generation for BCB, as the critic of IPL mentioned as 'IPL-a true corporate business' (Reddy, 2009, n.p.). Also, there is likely benefit for the franchisees of the BCB's proposed league. The IPL model brings appeal to gain more sponsorship for different sectors of the cricket business, business partnership and promotional options for BCB (Shams, 2011b).

\subsubsection{Nurturing local talents}

The IPL model provides the opportunity for the local players and under-22 year old players to play with world best cricketers (Shams, 2011a, 2011b), which helps them to gain big match temperament, as well as, additional tips from the best players to enhance and showcase their cricketing skills. Therefore, the league like IPL could provide the opportunity for BCB to nurture and develop the local players too.

\subsubsection{Promotional perspective}

IPL always promoted music and entertainment along with cricket. Musical bands perform in IPL matches to extend crowds' entertainment (Deccan Chronicle, 2011). Simultaneously, IPL has been using the Bollywood (Indian Film Industry) glamour along with cricket to promote the league. Bollywood has a huge appeal in India like cricket (Adarsh, 2009). IPL has been using the Bollywood glamour along with cricket to promote the league. The IPL management and all IPL franchisees signed Bollywood stars for promotion. The IPL obsession in India boomed on the stratosphere once the Bollywood stars joined IPL's promotion (Shams, 2011b). The glamorous promotion like the celebrity endorsement and musical band's performance during the break in a match may 
ensure crowds' aspiration along with the cricket.

These four features of IPL is established as four of their many success factors in order to develop a successful cricket business, along with further development of cricket as sport in India (Shams, 2011b). Furthermore, BCB could utilize these four factors lucratively in order to gain success from a domestic Twenty 20 cricket league, similar to the IPL. Therefore, the appropriate utilization of the relevant common feature of the established and emerging markets would reinforce the business management replication opportunity in emerging market, if the feature can be verified as viable for the emerging market, whereas the features are already established as success factors in the established market.

\subsection{Relevant prior exposure of the emerging market}

Limited exposure of BCB has been identified in terms of organizing cricket business like IPL, which are:

\subsubsection{Familiarity with the Twenty20 league}

$\mathrm{BCB}$ is already in a step forward to launch a country wide Twenty20 professional cricket league like IPL. Since, there are two Twenty 20 cricket tournaments that have already been started in Bangladesh. Among them, the 'Bigboss T20 Championship' is organized by BCB as a Dhaka (the capital of Bangladesh) metropolitan based club cricket and the 'Port City Cricket League (PCL)', organized by Chittagong Divisional Sports Association as a Chittagong (the second major city of Bangladesh) based club cricket, approved by BCB. Both tournaments' inaugural season was 2009 (Bangladesh Cricket, 2009; Majumder, 2009). Consequently, BCB has some sort of experience to organize Twenty20 cricket league, which would be an advantage to launch a country-wide Twenty20 cricket league like IPL, although only the cricket clubs participate the 'Bigboss T20' and the 'PCL' instead of any franchisee based full professional cricket team like IPL.

\subsubsection{Cricket auction in Bangladesh market}

The PCL introduced the concert of auction in Bangladesh cricket in 2009 for the first time (The New Nation, 2009), although the PCL's auction is concerned only with the players' auction instead of franchisee auction. As a consequence, the country-wide Twenty 20 cricket auction like IPL will not be very unusual for BCB.

\subsubsection{Potential of Twenty 20 cricket in Bangladesh market}

The inaugural seasons of both the 'Bigboss T20' and the 'PCL' have received enormous popularity in the market and success in terms of revenue generation (Molla, Das, \& Ahamed, 2009). Consequently, BCB can get optimism in terms of popularity for introducing the proposed country-wide Twenty 20 cricket league like IPL.

\subsubsection{Corporate culture in Bangladesh cricket}

BCB already has had experience to run a 'Domestic Corporate Cricket League', which is a capital based fifty over one day match tournament. The participants of the Corporate Cricket League (2007) are twelve corporate houses of Bangladesh. The corporate houses pay the top players to own the league's title (Bangladesh Domestic Season, n.d.). Consequently, BCB has already made another step forward to work with corporate houses and top business owners as a prospective franchisee of the BCB's proposed country-wide Twenty 20 cricket league. Such an exposure of BCB to work with corporate houses would be beneficial for BCB to run a country-wide franchisee based cricket league like IPL, as the critic of IPL mentioned that 'IPL-a true corporate business' (Reddy, 2009, n.p.).

\subsubsection{Local exposure of cricket broadcasting}

The Bangladeshi television channels already have gained experience in live cricket telecasting, which demands much more technical skill and resources than most other sports (Majumder, 2009; The New Nation, 2009). As per ICC (2011) cricket rating, Bangladesh is number ninth test country among ten test countries and 
number ninth one day international country among thirteen one day international countries. Consequently, if the international broadcasters do not show interest to telecast one of the weakest cricket country's domestic cricket because of less interest on the international media or because of not having a market among the viewers' of Bangladesh's domestic cricket or for any other reason, then BCB can still utilize the domestic channels to ensure the live telecast of the proposed league as the local TV channels are also paying (Majumder, 2009) a significant amount of money to the host to telecast cricket.

Consequently, such cricket business exposures of BCB, pertinent to the IPL business model would be a distinctive advantage for BCB to establish, maintain and enhance the paradigm shift cricket business concept of IPL in Bangladesh (Shams, 2011b).

\subsection{Implication of market relationship}

The most common branding aspect of IPL franchisee is 'city based naming' of the franchisees. Everyone has some soft corner, feelings, and emotions about their hometown. Some historical quotations have been quoted below from Think Exist (2009, n.p.), a quote and quotation website.

When you finally go back to your old hometown, you find it wasn't the old home you missed but your childhood (Ewing, 2001).

America is my country and Paris is my hometown (Stein, 1946).

An ardent supporter of the hometown team should go to a game prepared to take offense, no matter what happens (Benchley, 1945).

The IPL has used these hometown relationships based emotions and a feeling in their branding strategy so creatively like soccer does abroad (Manutd, 2009). The IPL's franchisees are named after the various regions' major cities of India, which accelerates the IPL's exhilarations among the mass people of India from the regionalism or regional spirit too (Reddy, 2009). Thus, the regionalism of the IPL's team becomes one of the causes for IPL's popularity. Similarly, BCB can choose the names of the major cities of Bangladesh as names for the franchisees of BCB's proposed country wide Twenty20 cricket league to spread up the spirit of the league among the mass people from the viewpoint of hometown relationship.

\subsection{Cultural issues of the established and the emerging markets}

Most importantly, the culture, ethnical background, life-style, socio-economic environment of two neighboring countries (Bangladesh and India) provide an inspiring platform to launch the country-wide Twenty20 cricket league like IPL in Bangladesh. Bangladesh and India as neighboring countries, share various similarities in terms of their cultural and ethnical background, life-style and socio-economic environment (Hussain, 2009; Indo Bangla Trade, 2009; Sub Regional Report, n.d.). On the other hand, business experts and authors have demonstrated the culture, ethnical background, life-style, socio-economic environment and so forth as significant factors in business as they influence consumer behavior or consumption patterns of consumers of a certain market (Mullie et al., 2009). As a result, marketers will have some crucial advantage on the business factors to market a country-wide Twenty20 cricket like IPL in Bangladesh as both countries share similar or almost close business factors, as their markets composed by the consumers, who share almost similar culture, ethnical background, life-style and socio-economic platform. Therefore, cultural issues of the established and the emerging markets would be critical in terms of replicating business management strategy from established market to emerging market.

\subsection{Endorsement and interest of the established market}

The IPL governing body is promoting the IPL concept to other boards of the cricketing nations and the ICC to introduce their domestic cricket league like IPL so that the cricket can reach in the next level by introducing a 
Business management replication from established market to emerging markets

global champions league comprising of the champion teams of the each nation's domestic league like UEFA (Union of European Football Association) Champions League or FIFA (Federation of International Football Association) World Club Cup (Vaishnav, 2009). Therefore, the IPL has launched a tremendous platform for BCB like other cricketing nations to gain success from the IPL business model, as well as, to help ICC to bring cricket in to the next level as a prospective global sport (Shams, 2011b). As a result, the emerging market could be able to utilize the vast experience of the established market in order to replicating business management strategy, if the emerging market could demonstrate that replicating the business model to the emerging market would be somehow beneficial for the established market too. For example, in this case, the IPL and the BCCI would be benefited by leading the cricket world and directing the ICC in order to spread up the IPL cricket extravaganza.

\section{Implication and conclusion}

The paradigm shift in cricket marketing through IPL is nothing but the marketing of immensely popular version of the game, the Twenty20, which is treated as the future of the game (India Twenty20, n.d.) in the line of English Premier League and American National Basketball Association's marketing practice in India focusing on the global cricket industry. The runway success of IPL and the global brand image that BCCI gained in the global cricket industry through IPL allow BCCI even to invite the global auction for Indian national team's sponsorship (Sports News, 2009). IPL concept is simple: provide spectators with a fun, fast and cost-effective spectacle (Brown, 2007). Only Twenty20 form of cricket can be used as a marketing tool to create excitement in Europe and America (Miller, 2009). Moreover, the cricket world has been promoting to include the cricket in Olympic with the Twenty20 format of the cricket for the first time in Olympic history after the 1900 Olympic Games (Meher, 2009).

Accordingly, the Twenty 20 format of the game and associated business practices, similar to the IPL specify the potential revenue generating stream for BCB through a franchisee based Twenty 20 cricket league like IPL. Though the opportunity in Bangladesh may not be predictable like the incredible success of India considering the much smaller market size of Bangladesh than India, the population of Bangladesh is only 162.2 million whereas the population of India is 1,132 million at the end of 2009 according to Population Council (2009). Moreover, a number of other cricketing nations are trying to adapt the IPL model in their domestic league to boost up their revenue (Shams, 2011b).

The paper attempts to become aware of the critical factors that would be crucial to replicating business management strategies from established market to emerging market. The case of IPL's market and Bangladesh market have been considered here as established and emerging markets consecutively for the Twenty 20 format of cricket business. A comparative analysis between established and emerging markets has been presented from the IPL and Bangladesh market perspective, with the aim of interpreting the significance of the synthesized critical factors. Seven critical factors are identified from the findings of the study as crucial in case of replicating business management strategies from established market to emerging market. Therefore, the findings of the study influence managerial perception from the perspective of emerging market business strategies, while the strategies are learnt from any established market. Moreover, the emerging market's (the target market) norms, values, consumption pattern and other associated market issues need to be analyzed prior to implement the seven critical factors in order to replicating any strategy from established market to emerging market. The proper scanning of the market environment of the emerging market would be one of the most challenging issues here, prior to utilize any of the critical factors. All efforts could be futile due to an inaccurate identification of emerging market's latent needs and inaccurate understanding of the relevancy of any critical factor with the identified needs of the emerging market. Therefore, the implementation of the critical factors should follow only the given situation, underlying the market environment of the emerging market. 
Shams, S. M. R.

Acknowledgement: We appreciate BCB's encouragement to conduct the research on BCB, as well as approving and supporting the research.

\section{References:}

Adarsh, T. (2009). IPL hits Bollywood hard! Retrieved December 09, 2009, from http://www.bollywood.com/ipl-hits-bollywood-hard

A Dummies Guide to IPL. (2009). Digital Inspiration. Retrieved December 07, 2009, from http://www.labnol.org/sports/india-premier-league-t20-cricket/8153/

Bangla Cricket. (2006). Timeline of Bangladesh cricket'. Retrieved March 14, 2010, from http://www.banglacricket.com/History/timeline.php

Bangladesh Cricket. (2009). Abahoni clinch Bigboss T20 cricket title. Retrieved December 14, 2009, http://bangladeshcricket.com/news/abahani-clinch-bigboss-t20-cricket-title-221.html

Bangladesh Domestic Season. (n.d.). Domestic news. Retrieved December 15, 2009, from http://www.cricketworld.com/forum/forum_posts.asp?TID=3116

Bangladesh National Cricket Team. (2010). Article. Retrieved November 17, 2007, from http://en.wikipedia.org/wiki/Bangladesh_national_cricket_team

BBC. (2009). IPL confirms South Africa switch. Retrieved December 09, 2009, from http://news.bbc.co.uk/sport2/hi/cricket/7958664.stm

Brown, A. (2007). They may have created a monster in Twenty 20 cricket - it's a massive hit. Retrieved December 21, 2009, from http://www.smh.com.au/news/cricket/they-may-have-created-a-monster-in-twenty20-cricket--its-amassi ve-hit/2007/09/14/1189276983292.html

Corporate Cricket League. (2007). Participant of Grameenphone corporate cricket league-2006-07. Retrieved December 15, 2009, from http://www.tigercricket.com/Corporate06-07.aspx

Creswell, J. W. (1998). Qualitative inquiry and research design: Choosing among five traditions. Thousand Oaks, CA: Sage.

Cricket360. (2009). IPL is India's favorite source of entertainment. Retrieved December 112009 , from http://www.cricket360.com/2020-ipl-is-india-s-favourite-entertainment-source.html

Deccan Chronicle. (2011). To rock for the tuskers. Retrieved August 31, 2011, from http://www.deccanchronicle.com/tabloid/glam-sham/rock-tuskers-005

Dey, I. (1995). Reducing fragmentation in qualitative research in computer aided qualitative data analysis: Theory, methods and practice. London: Sage.

Gomm, R., Hammersley, M., \& Foster, P. (2001). Case study and generalization in case study method. London: Sage.

Hamilton, D. (1980). Some constructing assumptions about case study research and survey analysis in towards a science of the singular: Essays about case study in educational research and evaluation. Paper presented at the Centre for Applied Research Education Symposium, University of East Anglia, Norwich.

Hartley, J. (1994). Case studies in organizational research: Qualitative methods in organizational research, a practical guide. London: Sage.

Hartley, J. (2004). Case study research: Essential guide to qualitative methods in organizational research. London: Sage.

History of Bangladesh Cricket. (2010). Bangladesh cricket. Retrieved March 14, 2010, from http://hubpages.com/hub/HIstory-of-bangladesh-cricket

Home of IPL Cricket. (2009). Kingfisher airlines becomes official umpire partners. Retrieved December 19 2009, from http://www.iplcricketlive.com/page/94/

Hussain, D. (2009). Life and death in the Bangladesh-India margins. Retrieved December 15, 2009, from http://www.opendemocracy.net/article/life-and-death-in-the-bangladesh-india-margins

ICC. (2011). Rankings. Retrieved September 01, 2011, from 
Business management replication from established market to emerging markets

http://icc-cricket.yahoo.net/match_zone/team_ranking.php

Incredible Marketing Success. (2009). Indian Premier League - club cricket, but incredible marketing success.

Retrieved December 10, 2009, from

http://ezinearticles.com/?Indian-Premier-League---Club-Cricket,-But-Incredible-Marketing-Success\&id $=3143693$

Indian Premier League Cricket. (2009). About IPL. Retrieved December 07, 2009, from http://www.premierleaguecricket.in/about/

India Twenty20. (n.d.). Twenty20: Cricket's possible answer to football. Retrieved December 21, 2009, from http://www.indiatwenty20.com/cricket-vs-football.htm

Indo Bangla Trade. (2009). Indo-Bangla trade: Focus on the north east stakeholder consultation. Retrieved December 15, 2009, from

http://www.cuts-citee.org/pdf/Event-Focus_on_the_North_East_Stakeholder_Consultation_09Aug2009 . $\mathrm{pdf}$

IPL History. (n.d.). Sports in India. Retrieved December 19, 2009, from

http://www.iloveindia.com/sports/ipl/ipl-history.html

IPL Season Two. (2009). IPL season 2 - everyone happy with its share of pie. Retrieved December 19, 2009, from

http://www.cricket360.com/2374-ipl-season-2-everyone-happy-with-its-share-of-pie.html

Kamaluddin, S. (2009). Developed properly, tourism will be country's main foreign exchange earner in ten years. Retrieved December 11 2009, from http://www.bangladeshmonitor.net/news_detail.php?nhid=135\&CID $=4$

Lee, B. (2008). IPL has created history. Retrieved December 19, 2009, from http://www.rediff.com/cricket/2008/feb/21lee.htm

Mahadik, R., Prasad, S., Tawde, P., \& Lyer, P. (2009). IPL-a revolution in Indian sports and entertainment. Retrieved December 09, 2009, from http://www.scribd.com/doc/22765915/Rakesh-Mahadik-Pallavi-Tawde-Siny-Prasad-Poornima-Iyer

Majumder, A. (2009). Cricket-Bangladesh city plans to switch T20 league to Sharjah. Retrieved December 14, 2009, from http://uk.reuters.com/article/idUKDHA26272220090831

Manutd. (2009). The homepage of Manchester United's website. Retrieved December 10, 2009, from http://www.manutd.com/default.sps?pagegid=\{78F24B85-702C-4DC8-A5D4-2F67252C28AA $\}$ \&itype $=12977 \&$ pagebuildpageid $=2716 \& b g=1$

Marketing Teacher. (2009). SWOT analysis-Indian Premier League. Retrieved December 10, 2009, http://www.marketingteacher.com/SWOT/indian_premier_league_swot.htm

Maurya, A. (2009). Birth of cricketainment: A case study on sports marketing by board of control for cricket in India. Retrieved December 07, 2009, from http://papers.ssrn.com/sol3/papers.cfm?abstract_id=1353725

Meher, K. (2009). T20 cricket in Olympics is a great idea. Retrieved December 21, 2009, from http://www.theroar.com.au/2009/06/28/t20-cricket-in-olympics-is-a-great-idea/

Merinews. (2008). Miracle in cricket history. Retrieved December 18, 2009, from http://www.merinews.com/article/miracle-in-cricket-historyindian-premier-league/132943.shtml

Miller, A. (2009). Flintoff rejects ECB central contract. Retrieved December 19, 2009, from http://www.cricinfo.com/england/content/current/story/424813.html

Mullie, P., Guelinckx, I., Clarys, P., Degrave, E., Hulens, M., \& Vansant, G. (2009). Cultural, socioeconomic and nutritional determinants of functional food consumption patterns. European Journal of Clinical Nutrition, 63 (10), 1290-1296. doi:10.1038/ejcn.2009.89 <http://dx.doi.org/10.1038/ejen.2009.89>

Molla, M. A., Das, K. P., \& Ahamed, F. (2009). Bigboss T20 champion-Abahoni. The Bangla Barta, November, p. 31.

Muralidharan, R. (2009). Birth of cricketainment: A case study on sports marketing by board of control for cricket in India. Retrieved January 11, 2010, from http://my.opera.com/Muralyyy/blog/ipl-birth-of-cricketainment

Patil, A. (2009), Anurag Patil. Retrieved December 19, 2009, from 
Shams, S. M. R.

http://www.anuragpatil.com/wordpress/?p=74

Population Council. (2009). Population council-research that makes a difference. Retrieved December 21, 2009, from http://www.popcouncil.org/index.html

Rawnak, S. (2008). Indian premier league-the billion dollar baby. Retrieved December 18, 2009, from http://www.xomba.com/indian_premier_league_ipl_the billion_dollar_baby

Reddy, T. (2009). Patriotism and regionalism. Retrieved December 14, 2009, from http://www.thirumalreddy.co.cc/2009/06/patriotism-and-regionalism.html

Shams, S. M. R. (2011a). Relationship marketing perspectives of Indian Premier League: How the league ensures benchmark marketing management in first two seasons? Manuscript submitted for publication.

Shams, S. M. R. (2011b). A relationship marketing model to enable sustainable growth of the Bangladesh Cricket Board: A stakeholder causal scope analysis. Doctoral dissertation, Central Queensland University, Australia. Retrieved August 25, 2011, from http://library.cqu.edu.au/cgi-bin/chameleon?search=KEYWORD\&function=INITREQ\&skin=keyword

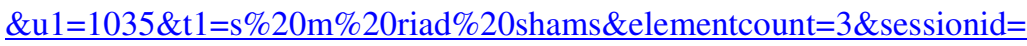

Sharma, K. (2008). IPL may make Oz cricketers' richest sports stars in Australia. Retrieved December 19, 2009, from http://www.topnews.in/sports/ipl-may-make-oz-cricketers-richest-sports-stars-australia-21336

Southasiabiz. (2007). World Cup-2007, greatest triumph for Bangladesh cricket. Retrieved January 15, 2008, from http://www.southasiabiz.com/2007/03/world_cup_2007_greatest_triump.html

Sports News. (2009). BCCI invites global bids for team sponsor. Retrieved December 21, 2009, from http://blog.taragana.com/sports/2009/11/02/bcci-invites-global-bids-for-team-sponsors-42948/

Stake, R. E. (1995). The art of case study research. Thousand Oaks, CA: Sage.

Stake, R. E. (2000). Case studies. Thousand Oaks, CA: Sage.

Stake, R. E. (2003). Strategies of qualitative inquiry. Thousand Oaks, CA: Sage.

Stavros, C. (2005). Relationship marketing in Australian professional sport: An organizational perspective. Unpublished doctoral dissertation. Griffith University, Australia.

Squirrell, J. (2009). The impact of twenty20. Retrieved December 18, 2009, from http://twenty20-cricket.suite101.com/article.cfm/the_impact_of_twenty20

Sub Regional Report. (n.d.). Sub-regional report on India, Bangladesh, Pakistan, Sri Lanka and Nepal. Retrieved December 15, 2009, from http://actrav.itcilo.org/english/calendar/2000/A3_2069/work/SUBREGIONAL_REPORTS/subregrep.ht m

Tarafdar, S. (2009). IPL money making-all gainers and no losers. Retrieved December 18, 2009, from http://toostep.com/insight/ipl-2-all-gainers-no-losers

The Daily Star. (2006). Straight talk, world cup fever. Retrieved October 12, 2007, from http://www.thedailystar.net/2006/06/12/d60612020323.htm

The Daily Star. (2007). Tigers prove ICC right. Retrieved December 25, 2007, from http://www.thedailystar.net/2007/04/10/d70410041751.htm

The New Nation. (2009). 48 top cricketers go on 'auction' today to play in PCL T20'. Retrieved December 14, 2009, from http://nation.ittefaq.com/issues/2009/04/25/all0549.htm

The Twenty20. (2003). Origins of twenty20 cricket-how twenty20 cricket started. Retrieved December 19, 2009, from http://www.thetwenty20.com/origins-of-twenty20cricket.html

Think Exist. (2009). Hometown quotes. Retrieved December 10, 2009, from http://thinkexist.com/quotes/with/keyword/hometown/

UNP. (2009). IPL 1st season closure: Profit and loss! Retrieved December 19, 2009, from http://www.unp.co.in/f46/ipl-1st-season-closure-profit-and-loss-28802/

Vaishnav, D. (2009). A project report on Indian premier league. Paper presented at the Bhagwant University, Ajmer, India.

Yin, R. K. (2003). Application of case study research. Thousand Oaks, CA: Sage.

Yin, R. K. (2009). Case study research: Design and methods (4th ed.). Thousand Oaks, CA: Sage. 